\title{
Optimization of Starch from Indonesian Local Corn with Concentration Variation of Sodium Metabisuphite and Drying Time
}

\author{
Richie A. I. Chandra, Sriwidodo, Aliya Nur Hasanah, and Rahma Agustina
}

\begin{abstract}
Local corn produce starch with high whiteness, but has not been developed in the Pharmaceutical Industry. Starch is one of the raw materials that are used as an excipient of tablet. This study aimed to obtain corn starch as an excipient meets the standards and determine the effect of concentration sodium metabisulfite and drying time on the quality of starch. The research method using a completely randomized design with two factors, the concentration of sodium metabisulfite (3000 ppm, $2500 \mathrm{ppm}$ and $2000 \mathrm{ppm}$ ) and drying time ( 24 hours, 28 hours). Starch was isolated by the wet method and starch were analyzed qualitatively, tested physicochemical properties, and is characterized by instrument Fourier Transform Infrared (FTIR) and scanning electron microscope (SEM). Results of the analysis showed that the starch from the corn meet the standards as pharmaceutical excipients. Concentration Sodium metabisulfite has very significant effect on yield, moisture content, and sulfite residue while drying time significantly affect yield, moisture content, compressibility and sulfite residues. combined treatment of drying time and the concentration of sodium metabisulfite has significant effect on yield, $\mathrm{pH}$ and compressibility. 28-hour drying time and concentration of 2500 ppm Sodium metabisulfite give the best effect on the quality of corn starch.
\end{abstract}

Index Terms-Corn Starch, drying time, local corn, sodium metabisulphite, excipients.

\section{INTRODUCTION}

Based on the data from the Ministry of Health, it is found that $95 \%$ of raw materials of drugs in Indonesia are still dependent on imports [1]. Dependence on imported raw materials makes Indonesia a nation that is less self-sufficient in terms of raw materials, while Indonesia has abundant biodiversity and has great potential as a producer of raw material for medicine [2].

Starch is a raw material widely used in the food industry and pharmaceutical industry, namely as an excipient in pharmaceutical preparations such as fillers, binders, disintegrator tablets [3]. Starch is widely used in the pharmaceutical industry because it is inert, inexpensive, and white [4].

Corn is a plant producing starch with starch content of about 54.1 to $71.7 \%$ [5]. Corn is composed of various types of amylose and amylopectin starch in the form of low-to-high [6] High content of amylopectin can be found in the Local Corn

Manuscript received April 17, 2015; revised June 20, 2015.

The authors are with the Pharmacy Faculty, Universitas Padjadjaran, Indonesia (e-mail: richie.chandra@unpad.ac.id).
Pulut.

Local corn is white maize contained in several regions in Indonesia [7]. The advantages of local corn white are the color of corn and fairly high amylopectin content [8]. According to the Ohio State University extension in corn starch amylopectin content is glutinous almost 100\% [9].

In the process of corn starch isolation, soaking in sodium metabisulphite takes more than 20 hours at a temperature of $48-52{ }^{\circ} \mathrm{C}[10]$. According to Slamet, immersion in a solution of sodium metabisulfite can prevent browning reaction on starch made so that the resulting product will produce a brighter color. In addition, the sodium sulfite ion content metabisufit also damage the matrix proteins play a role in the endosperm of corn with a way of breaking the disulfide bonds of proteins that can facilitate the release of starch in the endosperm of corn [10].

Another stage in the isolation of starch is drying. The drying process to reduce the moisture content of the material and prevents spoilage microorganisms or materials due to enzymatic processes [11] which can affect the quality of the resulting starch.

This study was conducted to develop the use of local corn in Industrial raw materials and to determine the effect of immersion concentration Sodium metabisulfite and drying time on the quality and physicochemical properties of corn starch produced Indonesian local corn.

\section{PROCEDURE}

\section{A. Corn Starch Isolation}

Isolation of corn starch corn was finely done by cleaning the skin and hair of corn. Shell corn soaked with a solution of sodium metabisulfite concentration of $2000 \mathrm{ppm}, 2500 \mathrm{ppm}$ and $3000 \mathrm{ppm}$ for 24 hours at a temperature of $50^{\circ} \mathrm{C}$. Shell corn subsequently rinsed with distilled water $(1: 2)$ and drained. then finely milled corn grinding machine with the addition of distilled water (1:3) to form slurry, finely ground with the addition of distilled water (1:2) using a blender, the slurry were filtered using gauze and distilled water added about 1.5 liter accompanied by stirring so that separate between the left over corn flesh and starch suspension. Corn starch suspension was precipitated for 24 hours at room temperature. The precipitate formed is separated from the filtrate and included in the chamber which already contains distilled water. This deposition process was repeated twice each for 2 hours. Last precipitation process, added a solution 
of $0.1 \mathrm{~N} \mathrm{NaOH}$ and precipitated ( \pm 3 hours). The filtrate was then separated from the grains of starch and starch is washed with water to remove residual $\mathrm{NaOH}$, the washing process was repeated 5 times until $\mathrm{pH}$ starch neutral. The precipitate was separated from the filtrate, to then dried in an oven at $50^{\circ}$ $\mathrm{C}$ with drying time (24 hours and 28 hours). Starch crushed and sieved using a 80 and no.100 mesh sieve. Calculated \% yield of starch produced.

\section{B. Quality Controll and Physico Chemical Properties of Corn Starch}

To get the corn starch which meets the requirements as pharmaceutical excipients, required characterization of the maize starch include: Organoleptic, solubility, Microscopy, qualitative test with iodine, Losses drying, pH [12], Smoothness [13], $\mathrm{SO}_{2}$ residue levels [14], compressibility [15], specific gravity [16], microbial contamination [13], the degree of white [17], Heavy Metal Contamination [13] and corn starch characterization instrument method is by using Fourier Transform Infrared [18] and Scanning Electron Microscope [19]. Complete study randomized design with two factors that the results were compared with the requirements contained in literatur. Experiment was done with two replications of samples. The data were analyzed by Two Way ANOVA with significance level $\alpha=0.01$.

\section{RESULT AND DISCUSSION}

\section{A. Result of Isolation}

The results showed that the concentration of sodium metabisulfite soaking with $3000 \mathrm{ppm}$ resulted in the highest $\%$ yield (see Table I) compared to the concentration of sodium metabisulphite $2500 \mathrm{ppm}$ and $2000 \mathrm{ppm}$. The higher concentration of sodium metabisulfite then yield to the higher corn starch. This is because the dissolution of sodium metabisulfite in water resulting in the formation of $\mathrm{Na}^{+}$ion and bisulfite ion ( $\left.\mathrm{HSO}^{-}\right)$, bisulfite ion reacts with $\mathrm{H}^{+}$to form $\mathrm{SO}_{2}$. The use of $\mathrm{SO}_{2}$ is very important because of $\mathrm{SO}_{2}$ as a reducing agent capable of breaking the disulfide bonds that wraps matrix protein starch granules, so as to free the starch granules. Additionally $\mathrm{SO}_{2}$ able to create favorable conditions for the growth of lactic acid bacteria (Lactobacillus). The lactic acid produced by lactic acid bacteria can help the separation of starch and increase the amount of starch produced. Lactic acid can increase the softening seed, endosperm proteins dissolve and weaken the endosperm cell walls [20].

The yield of starch with a 24-hour drying time has starch yield greater than 28 hours drying time (see Table II). It is because the water content is evaporated more. This is consistent with the statement Desrosier where the longer the drying time the water content is evaporated more and more so that the weight of the material to be reduced and the resulting starch yield will be lower [21]. There is interaction between the concentration of sodium metabisulfite with drying time. Where the higher concentration of sodium metabisulfite and the shorter length of time drying the\% yield of starch produced will increase.

\section{B. Qualitative analysis of Corn Starch}

\section{1) Organoleptic}

From the organoleptic examination at six samples tested showed results in accordance with the standards in the USP-NF XXX XXV white starch, in the form of a fine powder has no odor and has no taste (see Table III). From the test results it can be concluded that the starch obtained from each different treatment has met the criteria required organoleptic in the USP-NF XXX XXV [12].

\section{2) Solubility}

From the testing that has been made known that the solubility of local corn starch at a concentration sticky Sodium metabisulfite and different drying time obtained starch solubility in water and ethanol $95 \%$ is not soluble (see Table III). This is consistent with the solubility properties of starch which is expressed in the United States Pharmacopeia-National Formulary XXX XXV [12].

Insolubility of corn starch is closely related to the carbohydrate content of corn starch, which generally contains $20 \%$ amylose and $80 \%$ amylopectin, which is known amylopectin insoluble in water.

\section{3) Results analysis of corn starch iodine test}

Identification of corn starch with sodium metabisulfite and the concentration of different drying is done by suspending the starch with water that is heated to form starch solution that viscous. Starch formed complex with iodine reagent that changes color to blue. This is caused by the molecular structure of the starch in the form of a spiral that will traped the iodine molecule and forming a blue color. When starch is heated, the spiral will be stretchable, iodine molecules apart so that the blue color disappears [22]. From the experimental results obtained from the 6 samples tested starch to form a blue color complex after the addition of iodine (see Table III).

\section{4) Microscopic}

The results of the microscopic appearance of the local corn starch at a concentration of sodium metabisulfite and different drying time showed no significant differences too, each sample shows the characteristic cross-sectional picture of corn starch as in the United States Pharmacopeia-National Formulary XXX XXV which are hillus in the middle, in the form of a real cavity or crevice numbered 2 through 5 , no lamella, and under visible light irradiation with a black cross shape cut at the hilum

\section{The Results of the Examination of the Physicochemical Properties of Corn Starch}

\section{1) Loss of drying}

Based on testing of 6 samples of starch with different treatment - found that all six different starch sample drying shrinkage still meet the requirements specified in the USP-NF $\mathrm{XXX}$ XXV $\leq 15 \%$. The results showed concentrations of sodium metabisulfite soaking 3000 ppm resulted \% higher drying shrinkage (see Table IV) compared with the concentration of sodium metabislufit 2500 ppm and 2000 $\mathrm{ppm}$. The greater concentration of sodium metabisulphite, the greater the drying shrinkage. This is not in line with the research conducted by Prabasini et al. (2013) which states that the greater the concentration of sodium metabisulphite 
then drying shrinkage is getting smaller due to the destruction of tissue by sulfite compounds which can speed up the drying process [23].

This may be due to differences in the amount of starch suspension produced in each treatment. In the treatment of sodium metabisulphite concentration of $3000 \mathrm{ppm}$ amount of starch suspension produced more while the area of drying and drying temperature is used as the starch concentration of 2500 ppm and 2000 ppm, it causes drying shrinkage by treatment with sodium metabisulphite 3000 ppm much larger.

Drying shrinkage with a 24-hour drying time has a drying shrinkage greater than 28 hours drying time (see Table V) this is consistent with Desrosier statement stating that the longer drying and higher drying temperatures cause the water content in the material so much evaporate the water content and the weight of the material is reduced. Interaction $\mathrm{Na}_{2} \mathrm{~S}_{2} \mathrm{O}_{5}$ concentration and drying time did not have a significant influence on the drying shrinkage.

\section{2) Sulfite residue}

Of the six samples of starch with different treatment, it was found that all six samples of starch still meet the requirements of sulfite residues listed in the USP-NF XXX XXV $\leq 50 \mathrm{ppm}$. The result showed $\mathrm{Na}_{2} \mathrm{~S}_{2} \mathrm{O}_{5}$ concentration of 3000 ppm soaking produce sulfite residual values are higher (table 4) compared with $\mathrm{Na}_{2} \mathrm{~S}_{2} \mathrm{O}_{5}$ concentration of $2500 \mathrm{ppm}$ and 2000 ppm. $\mathrm{SO}_{2}$ residual value increases with increase in the concentration of sodium metabisulfite this is due to the higher concentration of sodium metabisulfite is used, the more sulfites which binds to the aldehyde or ketone on reducing sugar and form a hydroxy compound sulfonate [24].

At the 24 hours drying time has sulfite residual values smaller than 28 hours drying time (see Table V). The longer the drying time, the higher the value of sulfite residues is consistent with the research Farida (2007) which states that the higher the temperature and the longer drying the moisture content of the material will be lower so that residual sulfite total is higher [25]. Interaction between Sodium metabisulfite concentration and drying time is not very significant effect on residual sulfite. Total absorption of sulphite in a material is influenced by several factors, including the size of the material, the use of $\mathrm{SO}_{2}$ concentration, temperature and time sulfuring, temperature and state during the drying process [26].

\section{3) Microbial contamination}

\section{- Total Plate Count}

Total plate count is a method to determine the number of bacteria in a sample. These tests are known to regulate the development of many bacteria samples, where the total bacterial dependent formation of bacteria in a growth medium and each resulting bacterial colony forming a single [27]. As for the number of colonies of bacteria present in the tested sample still qualify contained in NFPA 01-3727-1995 ie anaerobic bacteria for corn starch is smaller than! $06 \mathrm{CFU} /$ gram.

Based on the test results showed that sodium metabisulfite and drying time is not very significant effect on the number of bacterial colonies. Highest number of colonies obtained at treatment concentrations of sodium metabisulphite 2000 ppm and 28 hours drying time.
The difference in the number of colonies of bacteria in the sample may be caused by other factors such as lack of aseptic conditions or the processing of samples and sample storage is not good so the samples contaminated by bacteria originating either from the surrounding air and water used during the production process.

- Fungus Yeast

Figures mold/yeast showed a contamination of mold / yeast in the preparation being examined. Each dosage requires numeric limit mold/yeast are still considered safe particular. The calculation is performed for the number of 40-50 colonies. Figures molds/yeasts expressed as the number of colonies of mold/yeasts result multiplied by the dilution factor calculation. As for the number of colonies of bacteria present in the tested sample still qualify contained in NFPA 01-3727-1995 ie mold colony for corn starch is less than $104 \mathrm{CFU} /$ unit.

The results of the experiment showed that the concentration of sodium metabisulfite and drying time did not have a significant influence on the number of mold colonies. The highest number of colonies bacteria obtained at treatment concentrations of sodium metabisulphite $2000 \mathrm{ppm}$ and 24 hours drying time.

The difference in the number of fungal colonies in the sample may be caused by other factors such as lack of aseptic conditions or the processing of samples and sample storage is not good so contaminated by mold samples derived from either ambient air or work tools used.

\section{4) $p H$}

The results showed immersion $\mathrm{Na}_{2} \mathrm{~S}_{2} \mathrm{O}_{5}$ concentration $2000 \mathrm{ppm}$ resulted in higher $\mathrm{pH}$ (see Table IV) compared with $\mathrm{Na}_{2} \mathrm{~S}_{2} \mathrm{O}_{5}$ concentration of $2500 \mathrm{ppm}$ and 3000 ppm. this can be caused by several other factors came into effect in addition to the concentration of sodium metabisulfite ie $\mathrm{NaOH}$ with distilled water washing process is less than perfect so there are still many who are trapped in $\mathrm{NaOH}$ which causes the starch starch to slightly alkaline $\mathrm{pH}$, the process of mixing and starch deposition during the isolation process less precise.

The $\mathrm{pH}$ value affects the optimum gel formation. Optimum starch gel formation occurs at $\mathrm{pH}$ 4-7. Where high $\mathrm{pH}$ can cause changes in the functional properties of corn starch, which is more rapid gel formation, but its viscosity is reached sooner down and when the heating was continued viscosity will go down again. At $\mathrm{pH}$ 4-7 gel formation slower pace than $\mathrm{pH} 10$, but when the heating is continued, the viscosity does not change [22].

Drying time did not have a significant influence on the $\mathrm{pH}$ (see Table V) Where the $\mathrm{pH}$ value on a 24-hour drying time of 6.7 and the drying time of 28 hours the $\mathrm{pH}$ value of 6,6.Interaksi Na2S2O5 concentration and drying time has no influence significantly on $\mathrm{pH}$.

\section{5) Fineness}

The results showed all six samples still meet the requirements of the fineness based SNI 01-3727-1995 ie passes $>70 \%$ with a 80 degree mesh fineness of starch at a concentration of sodium metabisulphite $3000 \mathrm{ppm}$ and 2000 ppm have the highest degree of fineness is lower than the concentration of $2500 \mathrm{ppm}$ (see Table IV). based on that result, it can be presumed degrees of fineness is not only influenced by the concentration of $\mathrm{Na}_{2} \mathrm{~S}_{2} \mathrm{O}_{5}$ but rather 
influenced by several other factors came into effect in addition to the concentration of sodium metabisulfite one of which is influenced by the process of manufacture of starch that is in the process of milling and sieving the starch samples were less than perfect. Subtlety is closely related to grain size and determined to sift the powder with a sieve standar.Degree subtlety showed the powder particle size uniformity which would affect the homogenous distribution of the drug compound, the size of the particles and granules associated with the problem of compaction and tablet weight uniformity [28].

While the drying time is based on data obtained no significant effect on the degree of fineness (see Table V). There is no significant influence of the interaction drying time and the concentration of sodium metabisulfite to the degree of fineness.

\section{6) Compressability}

Based on the result showed that the value of the compressibility of samples from each treatment is still not eligible listed in the Handbook of Pharmaceitical excipients Fifth Edition is less than $30 \%$. The results showed compressibility starch at a concentration of sodium metabisulphite 3000 ppm and 2000 ppm have compressibility values higher than $2500 \mathrm{ppm}$ (see Table IV) it can be due to several other factors that take effect in addition to the concentration of sodium metabisulfite one of which is the distribution of grain size and shape partikel. The particle size is getting smaller and more delicate, the greater cohesiveness between particles, thereby increasing the value of the compressibility.

While the effect of drying time on the compressibility was found that the compressibility at 24 hours drying time is greater than the drying time of 28 hours (see Table V). The longer the drying time, the lower the water content. High water levels will make the bonds between the particles become stronger because of extensive contact between the surface of the powder riding. If the attractive force between powder particles is getting stronger, the powder will be more compact and even higher the compresibility.

\section{7) Thickness}

The results showed that the concentration of $\mathrm{Na}_{2} \mathrm{~S}_{2} \mathrm{O}_{5}$ immersion (see Table IV) and drying time (see Table V) have no significant effect on the gravity of the resulting starch. From the results of experiments that have been carried out the true density of the results obtained in each treatment nearing density value types are listed in the Handbook of Pharmaceutical excipients Fifth Edition is $1,478 \mathrm{~g} / \mathrm{cm} 3$. The weight of a substance is influenced by several other factors including the temperature, the volume of the substance, and the substance period measured viscosity of the substance.

\section{8) The degree of white}

Tests carried out on samples of white degree of starch with the best yield is the concentration of 3000 ppm Sodium metabisulfite with 24-hour drying time and standard corn starch (redwood). Color powder that will be used as an excipient in accordance with the requirements must be white in order not to affect the appearance of the resulting preparation [29]. Therefore, it was necessary to measure to measure the whiteness of the white color of the two samples. Testing is done by using a Hunter Reflectometer. Where the principle of tests performed by measuring the intensity of light reflected by the surface of the test sample with a wavelength of $457 \mathrm{~nm}$ using an appropriate filter and diffuse lighting equipment and observations have perpendicular. The whiteness of the test results of samples prepared starch has a value of whiteness $78.27 \% \pm 0.07$ while the standard white starch has a value of $79.65 \pm 0.04$ degrees. Based on ISO standard no special requirements for the minimum value of the degree of white corn starch, but the higher the percent degree of white starch, the better and more attractive physical appearance. The degree of starch as an excipient white sample plays an important role because of the color produced excipient can affect the color and physical appearance of the preparation prepared as in tablet dosage. From the measurement results seem values whiteness samples made has approached the value whiteness of standard starch (redwood) in the market.

\section{9) Heavy metal contamination}

Testing with AAS method was conducted to determine heavy metal contamination of lead $(\mathrm{Pb})$, Cadmium $(\mathrm{Cd})$, Copper $(\mathrm{Cu})$, iron $(\mathrm{Fe})$, mercury $(\mathrm{Hg})$ and arsenic (As) of local sticky corn starch. From the results of experiments that have been carried out on samples of starch to yield the best that starch samples with a concentration of $3000 \mathrm{ppm}$ Sodium metabisulfite and drying time 24 jam.didapatkan that the heavy metal content in the samples still meet the requirements specified in NFPA 01-3727 -, 1995 (see Table VI) From Table 6 it can be seen that the value of the metal content of iron $(\mathrm{Fe})$ has not met the requirements of the USP-NF XXX XXV. This could be because the content of the soil of each planting areas generally contain metals minerals in a certain amount, and there is also the possibility of the metal content of lead, copper, cadmium, mercury, arsenic and iron in small quantities [30]. In addition contamination can also occur from a tool used for the isolation of starch such as grinding machine which may be carried in the process of iron starch isolation. Metal contamination is very important, because of the metal exceeds the specified threshold can affect the health of the human body such as the nervous system and respiratory.

\section{Characterization of Corn Starch with Instrument Method}

\section{1) Fourier transform infrared (FTIR)}

Analysis of functional groups on the local sticky corn starch powder with the best yield and standard corn starch (redwood) was performed using instrument Fourier Transform Infrared (FTIR). The resulting spectrum of process analysis using FTIR instrument can be seen in Figure 1. The infrared spectrum of a standard corn starch (Redwood) indicates the main absorption at wave number $3375.9 \mathrm{~cm} \mathrm{-1}$ and $1644.7 \mathrm{~cm}-1$. Peaks at a wavelength of $3375.9 \mathrm{~cm}-1$ indicates the group hidroxil and wavelength $1644.7 \mathrm{~cm}-1$ indicates the group $\mathrm{C}-\mathrm{H}$ stretching. In the wave number of $860.9 \mathrm{~cm}-1$ showed the presence of $\mathrm{CH}$ oop group band.

On local corn starch sticky with the best yield indicates the main absorption at wave number $3337.3 \mathrm{~cm} \mathrm{-1}$ and 1644.2 $\mathrm{cm}-1$. Spectrum peaks at a wavelength of $3337.3 \mathrm{~cm}-1$ 
indicates the group hidroxil and wavelength $1644.2 \mathrm{~cm}-1$ indicates the group $\mathrm{C}-\mathrm{H}$ stretching. In the wave number of $1147.9 \mathrm{~cm}-1$ showed the presence of group C - O stretch, at 860.1 wave numbers show an oop group $\mathrm{CH}$ band

Based on the observations it can be concluded that the infrared spectrum of local sticky corn starch when compared with standard corn starch (redwood) gives similar spectrum and point out the similarity of functional groups.

\section{2) Scanning Electron Microscope (SEM)}

Observation by SEM performed at 2500x magnification to determine the general picture of the corn starch particles. SEM results can be seen in Fig. 2.
TABLE I: EFFECT OF CONCENTRATION SODIUM METABISULFITE AGAINST \% YIELD

\begin{tabular}{lc}
\hline Concentraion $\mathrm{Na}_{2} \mathrm{~S}_{2} \mathrm{O}_{5}$ & $\%$ yield \\
\hline $3000 \mathrm{ppm}$ & $43,53^{\mathrm{a}}$ \\
$2500 \mathrm{ppm}$ & $37,26^{\mathrm{b}}$ \\
$2000 \mathrm{ppm}$ & $29,94^{\mathrm{c}}$ \\
\hline
\end{tabular}

Note: The figure shows followed by the same letter are not significantly different at the level of $\alpha=0.1$

TABLE II: EFFECT OF DRYING TIME AGAINST \%YIELD

\begin{tabular}{lc}
\hline Drying time & $\%$ yield \\
\hline 24 hour & $39,58^{\mathrm{a}}$ \\
28 hour & $34,23^{\mathrm{b}}$ \\
\hline
\end{tabular}

Note: The figure shows followed by the same letter are not significantly different at the level of $\alpha=0.1$

TABLE III: QUALITATIVE TESTING RESUlTS STARCH SAMPLES

\begin{tabular}{|c|c|c|c|c|c|c|}
\hline Test & $\begin{array}{c}\text { 3000ppm (24 } \\
\text { hour) }\end{array}$ & $\begin{array}{l}3000 p p m \quad(28 \\
\text { hour) }\end{array}$ & $\begin{array}{l}2500 p p m \quad(24 \\
\text { hour) }\end{array}$ & $\begin{array}{l}2500 p p m \quad(28 \\
\text { hour) }\end{array}$ & $\begin{array}{l}\text { 2000ppm } \\
\text { (24 hour) }\end{array}$ & $\begin{array}{l}\text { 2000ppm } \\
\text { hour) }\end{array}$ \\
\hline Colour & White & White & White & White & White & White \\
\hline Taste & Tasteless & Tasteless & Tasteless & Tasteless & Tasteless & Tasteless \\
\hline Smell & Odorless & Odorless & Odorless & Odorless & Odorless & Odorless \\
\hline Solubility & Insoluble & Insoluble & Insoluble & Insoluble & Insoluble & Insoluble \\
\hline $\begin{array}{l}\text { Test with } \\
\text { Iodium }\end{array}$ & Positive & Positive & Positive & Positive & Positive & Positive \\
\hline
\end{tabular}

TABLE IV: THE INFLUENCE OF THE CONCENTRATION OF SODIUM METABISULPHITE ON PHYSICOCHEMICAL PROPERTIES

\begin{tabular}{|c|c|c|c|c|c|c|c|c|}
\hline $\begin{array}{l}\text { Concentration } \\
\mathrm{Na}_{2} \mathrm{~S}_{2} \mathrm{O}_{5}\end{array}$ & $\begin{array}{l}\text { drying } \\
\text { shrinkage }(\%)\end{array}$ & $\begin{array}{l}\text { sulfite } \\
\text { residues } \\
(\%)\end{array}$ & $\begin{array}{l}\text { colonies } \\
\text { bacteria } \\
(\mathrm{ALT})\end{array}$ & $\begin{array}{l}\text { mold } \\
\text { colonies } \\
(\mathrm{AKK})\end{array}$ & $\mathrm{pH}$ & fineness $(\%)$ & $\begin{array}{l}\text { Compresability } \\
(\%)\end{array}$ & $\begin{array}{l}\text { Weight } \\
\text { Type }\end{array}$ \\
\hline $3000 \mathrm{ppm}$ & $11,58^{\mathrm{a}}$ & $4,7^{\mathrm{a}}$ & $2,68 \times 10^{5}$ & 0 & $6,6^{b}$ & $99,6^{b}$ & $31,6^{\mathrm{a}}$ & $1,36^{\mathrm{a}}$ \\
\hline $2500 \mathrm{ppm}$ & $11,43^{\mathrm{a}}$ & $4,4^{\mathrm{b}}$ & $2,55 \times 10^{5}$ & 16,67 & $6,3^{\mathrm{c}}$ & $99,8^{a}$ & $29,1^{\mathrm{b}}$ & $1,25^{\mathrm{a}}$ \\
\hline $2000 \mathrm{ppm}$ & $10,21^{\mathrm{b}}$ & $4,0^{\mathrm{c}}$ & $20,98 \times 10^{5}$ & 83,3 & $7,1^{\mathrm{a}}$ & $99,5^{\mathrm{b}}$ & $31,3^{\mathrm{a}}$ & $1,21^{\mathrm{a}}$ \\
\hline
\end{tabular}

Note: The figure shows followed by the same letter are not significantly different at the level of $\alpha=0.1$

\begin{tabular}{llllllll}
\multicolumn{7}{c}{ TABLE V: EFFECT OF DRYING TIME ON PHYSICOCHEMICAL PROPERTIES } \\
\hline drying time & $\begin{array}{l}\text { drying } \\
\text { shrinkage }(\%)\end{array}$ & $\begin{array}{l}\text { sulfite } \\
\text { residues } \\
(\%)\end{array}$ & $\begin{array}{l}\text { colonies of } \\
\text { bacteria } \\
(\text { ALT) }\end{array}$ & $\begin{array}{l}\text { mold } \\
\text { colonies } \\
(\text { AKK) }\end{array}$ & pH & $\begin{array}{l}\text { fineness }(\%) \\
\text { Compresability } \\
(\%)\end{array}$ & $\begin{array}{l}\text { Weight } \\
\text { Type }\end{array}$ \\
\hline 24 hour & $11,72^{\mathrm{a}}$ & $3,84^{\mathrm{b}}$ & $9,03 \times 10^{5}$ & 63,88 & $6,7^{\mathrm{a}}$ & $99,7^{\mathrm{a}}$ & $32,08^{\mathrm{a}}$ \\
28 hour & $10,43^{\mathrm{b}}$ & $5,01^{\mathrm{a}}$ & $8,45 \times 10^{5}$ & 2,77 & $6,6^{\mathrm{a}}$ & $99,6^{\mathrm{a}}$ & $1,38^{\mathrm{a}}$ \\
\hline
\end{tabular}

Note: The figure shows followed by the same letter are not significantly different at the level of $\alpha=0$

TABLE VI: HEAVy METAL CONTAMINATION OF TEST RESUltS ON SAMPLES OF STARCH

\begin{tabular}{ccc}
\hline type Metal & total $(\mathrm{ppm})$ & Requirements $(\mathrm{ppm})$ \\
\hline $\mathrm{Pb}$ & $<0,040$ & 1 ( SNI 01-3727-1995) \\
$\mathrm{Cu}$ & 0,18 & $10($ SNI 01-3727-1995) \\
$\mathrm{Cd}$ & 0,005 & $40($ SNI 01-3727-1995) \\
$\mathrm{As}$ & $<0,003$ & $0,5($ SNI 01-3727-1995) \\
$\mathrm{Fe}$ & 21,3 & $10($ USP XXX-NF XXV) \\
$\mathrm{Hg}$ & 0,005 & $0,05($ SNI 01-3727-1995) \\
\hline
\end{tabular}

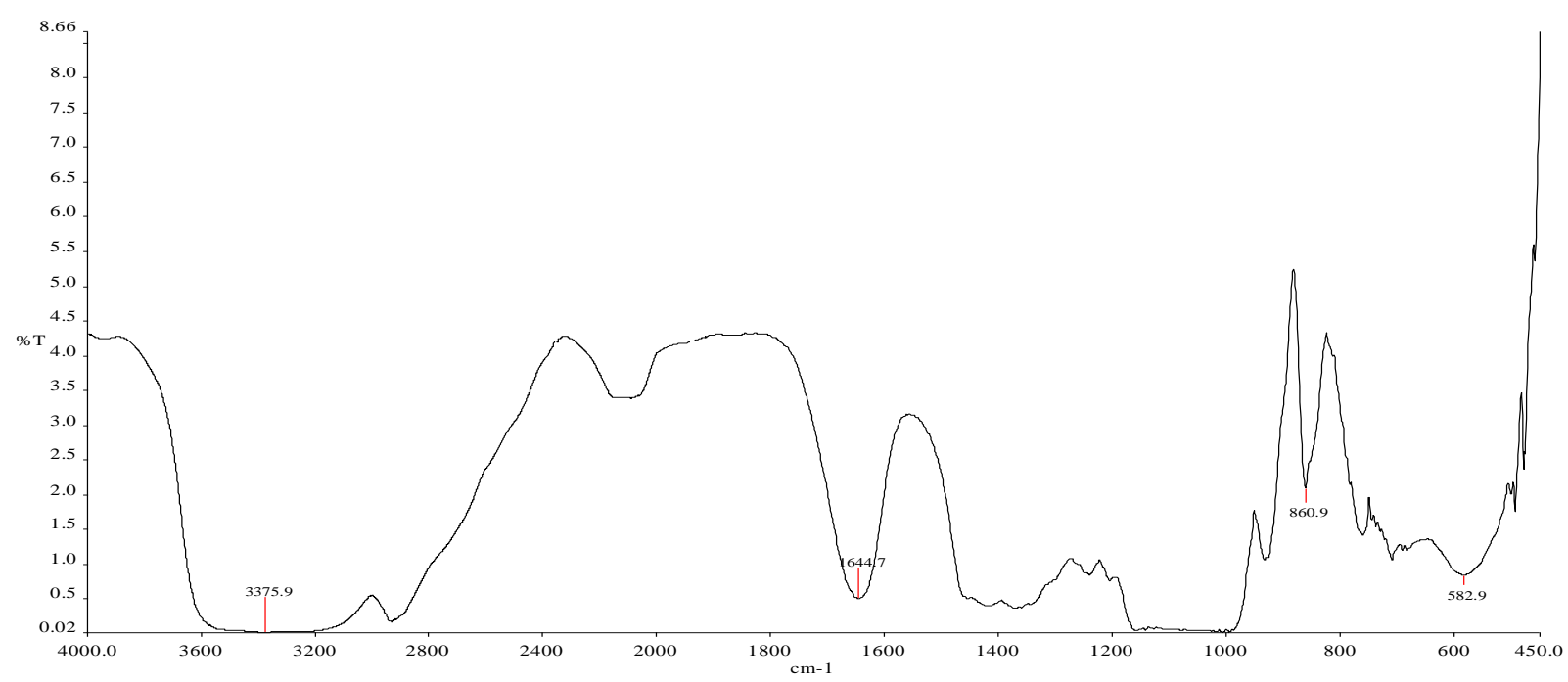

(a) 


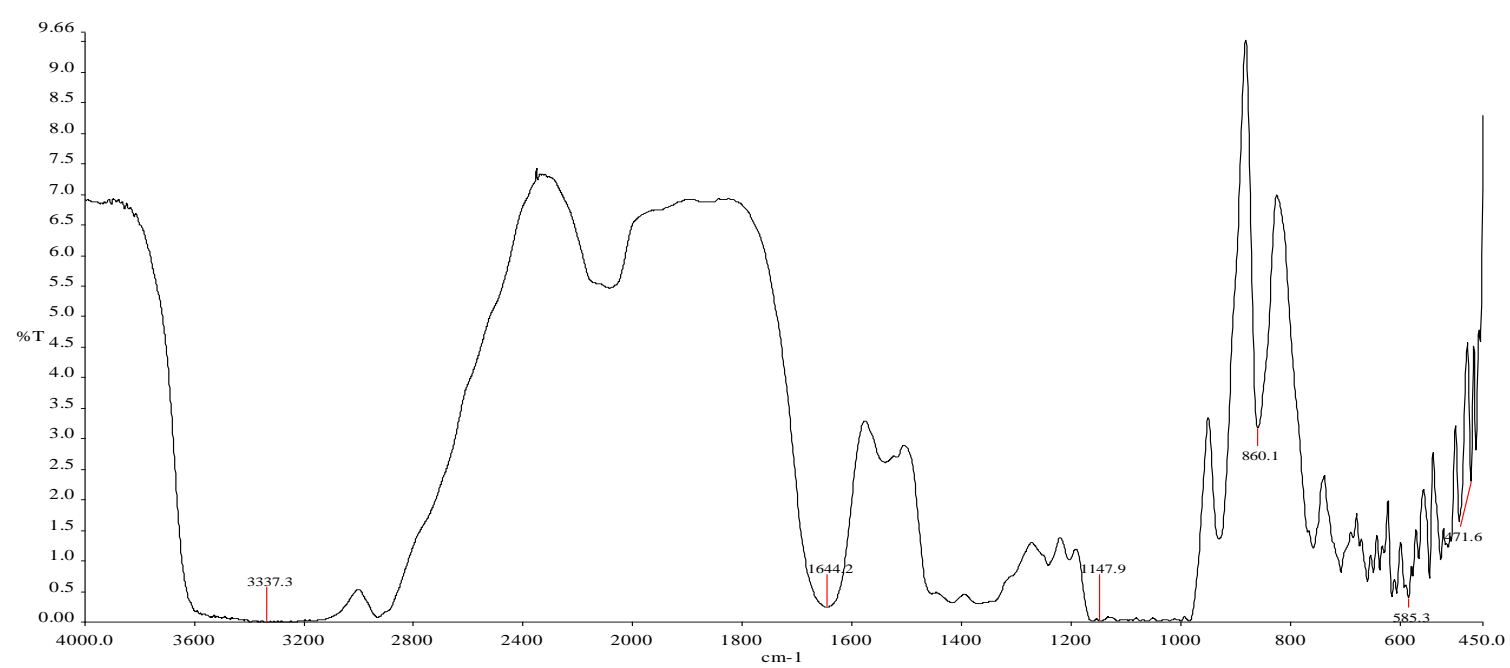

(b)

Fig. 1. The results of the test with FTIR (a) standard corn starch (redwood); (b) sample R1L1 starch (sodium metabisulphite 3000 ppm and 24 hours drying time).

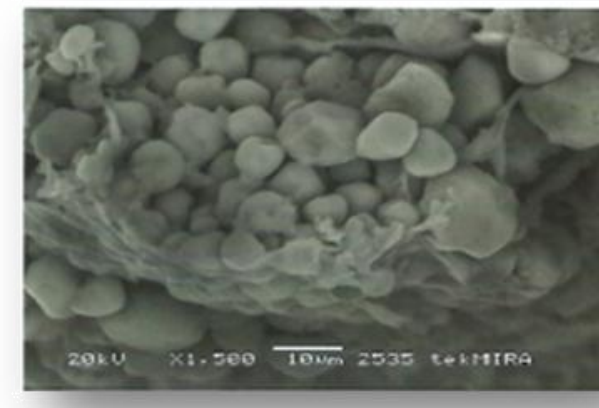

(a)

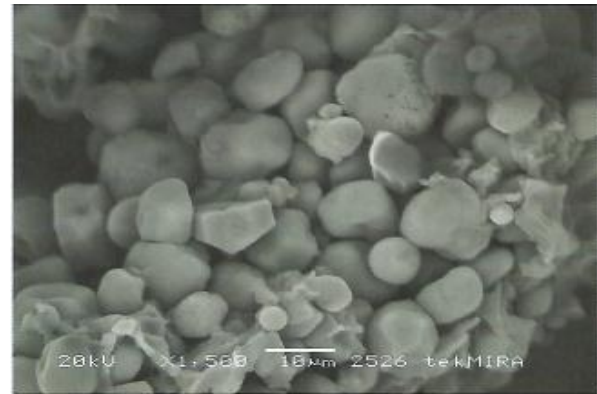

(b)

Fig. 2. Results of SEM (a) Samples of starch in the best yield (b) standard starch (redwood)

From the observation with SEM, it appears that the particles of corn starch and corn starch sticky standard (redwood) are round, angled responsibility and tetragonal. At the local corn starch sample standard sticky and showed agglomeration fairly evenly. In addition, many individuals either corn starch sample and standard plate-shaped arch with large spaces. The shape of the curved plate with large spaces and uneven particle surface even somewhat rough cause starch has a pretty good porosity. However there are certain individuals either on local corn starch samples sticky and disability standards such as thinning, fractures and broken individual starch this can be due to initial treatment during theprocess of isolation of starch as the starch particle size reduction stage with grinding tool which causes the starch granules formed less than perfect and can also be caused by the heating process is too long or at too high a temperature that causes the starch granules and broken.

\section{CONCLUSIONS}

Based on the research that has been conducted, FTIR and SEM showed that the characteristics of corn starch obtained from local sticky rice starch meets the standards as pharmaceutical excipients as listed in the USP-NF XXX XXV, SNI 01-3727-1995 and Handbook of Pharmaceitical excipients Fifth Edition.
Based on research that has been done can be seen that the concentration of sodium metabisulphite was highly significant $(\alpha=0.01)$ to the yield, drying shrinkage, and high residual concentrations of sodium metabisulfite sulfit. The value of yield higher, moisture content and residual sulfite will be even greater. concentration of sodium metabisulphite no significant effect on weight and type of microbial contamination. Drying time was highly significant $(\alpha=0.01)$ to the yield, moisture content, residual sulfite and compressibility. The longer the drying time, the lower the value of the yield, moisture content and compressibility but may increase the value of residual sulfite. Drying time has no significant effect on specific gravity, $\mathrm{pH}$, fineness and microbial contamination. The interaction between the concentration of sodium metabisulphite and drying time significantly affect yield, $\mathrm{pH}$ and compressibility. The higher concentration of sodium metabisulphite and old drying, the lower value of the yield, $\mathrm{pH}$ and compressibility.

\section{REFERENCES}

[1] Indonesia Ministry of Health. (2012). Ketersediaan Bahan Baku Obat. [Online]. Available: http://www.depkes.go.id/article/print/1860/ketersediaan-bahan-bakuobat.html

[2] T. Tjokrosaputro, "Corn and starch development in Indonesia," in Proc. International Workshop on Corn and Starch Deep Processing Technology, Changchun, Jilin, China, September 2000, pp. 1-10. 
[3] R. C. Rowe, P. J. Sheskey, and S. C. Owen, Handbook of Pharmaceutical Excipients, $5^{\text {th }}$ ed., Pharmaceutical Press, London and American Pharmaceutical Association, Washington DC, 2006, pp. 726-730.

[4] J. Swabrick, Encyclopedia of Pharmaceutical Technology, $3^{\text {rd }}$ ed., New York: Informa Healthcare, USA, Inc., 2007.

[5] R. Nur and Suarni. (2008). Teknologi Pengolahan Jagung. Balai Besar Penelitian dan Pengembangan Pasca panen. [Online]. Available: http://www.balitsereal.litbang.deptan.go.id.pdf

[6] Jatmiko. (2009). Mengenal benih jagung. [Online]. Avaiable: http://binatanimakmur.com

[7] N. A. Subekti, R. Syafaruddin, and E. dan S. Sunarti. (2008). Morfologi Tanaman dan Fase Pertumbuhan Jagung. [Online] Available: http:/balitsereal.litbang.deptan.go.id/bjagung/empat.pdf

[8] S. dan Faesal, Usaha Tani Jagung Pulut Mendukung Kemandirian. Pangan Dan Peningkatan Pendapatan Petani, Balai Serealia Pangan, 2009.

[9] Ohio State University Extension. (2010). Spe-cialty corns: Waxy, high-aiamylose, high-oil, and high-lysine corn. [Online]. Available: http://ohioline.osu.edu/agf-fact/0112.html

[10] G. Wahl, Present Knowledge of the Maize Steeping Process, Starch, 1969, vol. 21, pp. 62-73.

[11] Adawyah, Pengolahan dan Pengawetan Ikan, Bumi Aksara: Jakarta, 2007.

[12] Ministry of Health and Human Services US, The United States Pharmacopoeia, $13^{\text {th }}$ revision, The National Formulary, $25^{\text {th }}$ ed., Twinbrook Parkway, Rockville, Maryland: United States Pharmacopoeial Convention, Inc. 1223, 2007.

[13] Badan Standardisasi Nasional, Pati Jagung (SNI 01-3727-1995). Jakarta: Badan Standardisasi Nasional, 1995.

[14] Association of Official Analytical Chemist, Official Methods of Association of Official Analytical Chemist, Washington DC, 2007.

[15] M. E. Aulton, Pharmaceutics: The Science of Dosage Form, $2^{\text {nd }}$ edition. Edinburg: Churchill Livingstone, 2003.

[16] Badan Standardisasi Nasional, Cara Uji Makanan dan Minuman (SNI 01- 2891-1992), Jakarta: Badan Standardisasi Nasional, 1992.

[17] Badan Standardisasi Nasional, Cara Uji Faktor Pantul Biru Cahaya Baur(Derajat Putih ISO) (SNI ISO 24702010), Jakarta: Badan Standardisasi Nasional, 2010.

[18] A. Latif, Anwar, and S. Noor, "Two-step synthesis and characterization of carboxymethylcellulose from rayon grade wood pulp and cotton linter," Jour. Chem. Soc. Pak, vol. 29, no. 2, pp. 143-150, 2007.

[19] H. D. Heydarzadeh, G. D. Najafpour, and A. A. Nazari-Moghaddam, "Catalyst-free conversion of alkali cellulose to fine carboxymethyl cellulose at mild conditions," World Applied Sciences Journal, vol. 6, no. 4, pp. 564-569, 2009.

[20] L. A. Johnson, J. B. May, and W. Milling, "The basis for corn refineries," Chemistry and Technology, $2^{\text {nd }}$ ed, American Association of Cereal Chemistry Inc, st. Paul, Minnesota, USA.

[21] N. W. Desrosier, Teknologi Pengawetan Pangan (M. Muljoharjo, penerjemah). UI Press: Jakarta, 1988

[22] F. G. Winarno, Kimia Pangan dan Mineral, Singapore: Periplus Edition, 2008.

[23] H. Prabasini, D. Ishartani, and D. Rahadian, "Kajian Sifat Kimia dan Fisik Tepung Labu Kuning (Cucurbita moschata) dengan Perlakuan
Blanching Dan Perendaman Dalam Natrium Metabisulfit $\left(\mathrm{Na}_{2} \mathrm{~S}_{2} \mathrm{O}_{5}\right)$, Surakarta : Jurnal Teknosains pangan, 2013.

[24] M. Apandi, Teknologi Buah dan Sayur.Alumni, Bandung, 1984.

[25] R. Farida, Pengaruh konsentrasi Natrium Metabisulfit dan suhu pengeringan terhadap mutu pati biji alpukat (Persea americana mill), 2007.

[26] T. Susanto and B. Saneto, Teknologi Pengolahan Hasil Pertanian, Bina Ilmu, Surabaya, 1994.

[27] D. M. Natsir and Sartini, Instrumentasi Mikrobiologi Farmasi Dasar, Laboratorium Mikrobiologi dan Bioteknologi, Makasar, 2005.

[28] R. Voigt, Buku Pelajaran Teknologi Farmasi, Penerjemah: Soendani, 1994.

[29] A. S. Sagitaria, Preparasi dan Karakterisasi Selulosa Mikrokristal dari Nata De Soya sebagai Eksipien Tablet dengan Metode Kempa Langsung, Jatinangor: Universitas Padjadjaran, 2011.

[30] J. Wargiono and B. S. dan Kartika, Dinamika Budidaya Ubi kayu.Jakarta: Badan Litbang Pertanian, 2009, pp. 138-167.

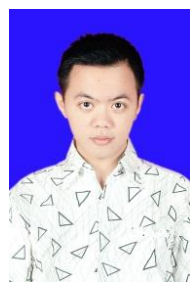

Richie A. I. Chandra was born in Indoesia on $15^{\text {th }}$ August, 1984. He graduated from Pharmacy Bachelor Program, Universitas Padjadjaran, Bandung, Indonesia, 2007 and Pharmacy Master Program from Universitas Gadjah Mada, Yogyakarta, Indonesia, 2009

He is currently working as a lecturer in Departement of Pharmaceutical Faculty Pharmacy Universitas Padjadjaran. His research interests are pharmaceutical technology, biotechnology and nanotechnology. He is a member of Cosmetic Societies Scientist Indonesia.

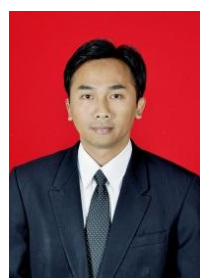

Sriwidodo was born in Indoesia on 30 $0^{\text {th }}$ March, 1974. He graduated from Pharmacy Bachelor Program, Universitas Padjadjaran, Bandung, Indonesia, in 1997 and Pharmacy Master Program from Universitas Padjajdaran, Bandung, Indonesia in 2007

$\mathrm{He}$ is currently working as a lecturer in the Departement of of Pharmaceutical Faculty Pharmacy Universitas Padjadjaran. His research interests are pharmaceutical, and biotechnology.

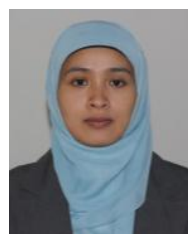

Aliya Nur Hasanah was born in Indoesia on $12^{\text {th }}$ February, 1979. She graduated from Pharmacy Master Program from Institute Technology Bandung, Bandung, Indonesia in 2007. She is currently working as a lecturer in the Departement of of Pharmacochemistry Faculty Pharmacy Universitas Padjadjaran. Her research interests are molecular imprinting and separation method.

Rahma Agustina was born in Tangerang on $26^{\text {th }}$ August, 1992. She is a student in Bachelor Program, Pharmacy Faculty, Universitas Padjadjaran, Indonesia. 